\title{
Penyimpangan Pemakaian Kaidah Fungtor Kalimat Pada Artikel Jurnal
}

\author{
Priscila Felicia Elu ${ }^{\mathrm{a}, 1}$ dan R. Kunjana Rahardi ${ }^{\mathrm{a}, 2}$ \\ ${ }^{\text {a } U n i v e r s i t a s ~ S a n a t a ~ D h a r m a, ~ Y o g y a k a r t a, ~ I n d o n e s i a ~}$ \\ ${ }^{1}$ priscilafelicia96@gmail.com; ${ }^{2}$ kunjana.rahardi@gmail.com

Article info A B S T R A C T \\ Article history: \\ Received: 16-02-2020 \\ Revised : 10-05-2020 \\ Accepted:28-09-2020 \\ Conjunctions are part of the construction of a sentence. In \\ writing, there is often a deviation from the sentence function rules \\ related to the conjunction. This study aims to describe the errors \\ of sentence functions in Indonesian. This qualitative research \\ data source is the Indonesian Language Education Master \\ Program students, Sanata Dharma University Yogyakarta. This \\ research's data are sentences in journal articles that deviate from \\ the rules of Indonesian sentence functions. From 100 data, 45 \\ functional errors, 31 conjunction errors, four-function, and \\ conjunction errors at once, and 20 idea ineffectiveness. These \\ functions' errors were categorized into 14 errors in the subject \\ function, 15 errors in the predicate function, three errors in the \\ object function, and 13 errors for both the subject and predicate \\ functions.
}

Keywords:

article

conjunction

functional errors

Indonesian

Konjungsi merupakan bagian dari konstruksi sebuah kalimat. Dalam sebuah tulisan, acap kali terjadi penyimpangan kaidah fungtor kalimat berkaitan dengan konjungtor. Penelitian ini bertujuan untuk mendeskripsikan kesalahan fungtor-fungtor kalimat berbahasa Indonesia. Sumber data penelitian kualitatif ini adalah para mahasiswa Program Magister Pendidikan Bahasa Indonesia, Universitas Sanata Dharma Yogyakarta. Data penelitian ini adalah kalimat-kalimat dalam artikel jurnal yang menyimpang dari kaidah fungtor-fungtor kalimat bahasa Indonesia. Dari 100 data, ditemukan 45 kesalahan fungtor, 31 kesalahan konjungtor, empat kesalahan fungtor dan konjungtor sekaligus, dan 20 ketidakefektifan gagasan. Adapun kesalahan fungtor tersebut dikategorisasikan menjadi 14 kesalahan pada fungtor subjek, 15 kesalahan pada fungtor predikat, tiga kesalahan pada fungtor objek, dan 13 kesalahan untuk fungtor subjek dan predikat sekaligus.

Copyright $\odot 2020$ Institut Agama Islam Negeri Syekh Nurjati Cirebon. All rights reserved.

\section{PENDAHULUAN}

Kendati terdapat kaidah kebahasaan yang telah dipaparkan secara jelas dalam berbagai literatur, penyimpangan yang ditemukan dalam proyek penulisan tetap saja tidak dapat dihindari. Mahasiswa tidak terlepas dari kesalahan kaidah tata bahasa, terutama dalam penulisan kalimat sekali pun mendapat kesempatan seluas-luasnya untuk mempelajari penggunaan kalimat (Mariyana, 2019). Melalui penelitian ini, dideskripsikan penyimpangan kaidah fungtor kalimat yang terjadi dalam penulisan artikel jurnal. Artikel jurnal ditulis sebagai karya akademik yang wajib ditulis oleh para akademisi. Mahasiswa, dosen, ilmuwan, dan insan 
akademik lainnya wajib menulis hasil penelitian dan pemikiran dalam suatu karya ilmiah (Azmi \& Bahry, 2018). Untuk itu, kaidah kebahasaan yang dipelajari dalam bangku perkuliahan pada dasarnya merupakan bekal bagi para akademisi dalam memenuhi tanggung jawab.

Dalam menulis sebuah artikel jurnal, peneliti atau penulis perlu menguraikan gagasan maupun hasil penelitiannya dengan jelas menggunakan kalimat yang mampu memberikan imajinasi bagi pembaca. Gagasan yang diurai dalam bentuk kalimat pada dasarnya memiliki fungsinya masing-masing. Gagasan berupa kalimat tersebut sebagai ujaran yang berisikan pikiran yang tersusun dari minmal subjek dan predikat (Busri \& Badrih, 2018). Fungsi dalam kalimat itu berkaitan antara satu dengan yang lain dan diatur oleh kaidah keterkaitan fungtorfungtor, seperti pernyataan yang menjelaskan bahwa setiap kalimat paling tidak memiliki predikat didalamnya. Namun pada kenyataannya, masih terdapat penyimpangan bentuk kaidah fungtor kalimat dalam kegiatan menulis.

Fungsi sintaksis disebut sebagai fungtor atau jabatan dalam kalimat. Fungsi sintaksis pada dasarnya merupakan unsur formal yang tidak terikat oleh kategorial dan semantis tertentu (Verhaar dalam Suhardi, 2013). Fungsi ini juga dapat dipadankan dengan istilah fungtor yang meliputi subjek (S), predikat $(\mathrm{P})$, objek $(\mathrm{O})$, pelengkap $(\mathrm{Pel})$, dan keterangan $(\mathrm{K})$. Dalam tulisan ini, istilah fungtor akan lebih sering digunakan dibandingkan dengan istilah fungsi. Selanjutnya, subjek, predikat, objek, pelengkap dan keterangan ditulis dengan S, P, O Pel, dan K.

Seperti yang telah diketahui bahwa lima fungtor dalam kalimat tidak selalu hadir bersamaan dalam sebuah konstruksi. Biasanya, unsur yang lebih sering hadir adalah $\mathrm{S}$ dan $\mathrm{P}$, sehingga kedua fungtor tersebut biasa disebut sebagai unsur wajib dalam sebuah klausa maupun kalimat. Sebuah kalimat memiliki unsur wajib dan unsur tak wajib (Alwi, dkk., 2003). Unsur wajib itu berupa S dan P. Unsur ini terdiri atas konstituen yang tidak dapat dihilangkan. Unsur-unsur lain seperti O, P, $\mathrm{K}$, dan Pel merupakan konstituen tak wajib yang bisa saja tidak disertakan dalam konstruksi kalimat.

Fungtor pertama adalah subjek (S). Subjek merupakan bentuk gramatikal di dalam klausa yang berpotensi berperan sepagai pelaku, pengalam, peruntung, ukuran, dan pokok (Khairah \& Ridwan, 2015). Subjek pada kalimat transitif akan menjadi pelengkap apabila kalimat itu dipasifkan. Adapun beberapa makna unsur pengisi S, seperti: pelaku, alat, sebab, penderita, hasil, tempat, penerima, pengalam, dikenal, dan terjumlah. Makna unsur pengisi satu fungsi berkaitan dengan makna yang dinyatakan oleh unsur pengisi fungsi yang lain (Ramlan, 2005).

Fungtor selanjutnya yaitu predikat (P). Predikat merupakan unsur terpenting dalam sebuah konstruksi klausa maupun kalimat. Fungtor P memiliki beberapa ciri, seperti: 1) $\mathrm{P}$ sebagai unsur pokok disertai unsur $\mathrm{S}$ di sebelah kiri atau sebelumnya dan (jika ada) diikuti oleh unsur O, Pel, dan/atau K di sebelah kanan, 2) $P$ dapat diisi oleh kata/frasa verbal atau kata/frasa nonverbal (Suhardi, 2013). Berdasarkan strukturnya, S dan P dapat dipertukarkan tempat (Ramlan, 2015).

Objek merupakan konstituen kalimat yang kehadirannya dituntut oleh predikat yang berupa verba transitif dalam kalimat aktif (Alwi, dkk., 2003). Untuk mengidentifikasi objek, perlu memperhatikan jenis predikat yang dilengkapinya dan ciri khas dari objek itu sendiri. Kehadiran objek dalam struktur klausa dituntut oleh predikat berupa verba transitif pada kalimat aktif (Khairah \& Ridwan, 2015). Hal paling penting yang perlu diperhatikan dalam fungsi ini, yaitu fungsi objek 
berada langsung di belakang predikat dan tidak dapat dipindahkan ke depan predikat atau ke depan subjek.

Fungtor selanjutnya adalah pelengkap (Pel). Pelengkap kerap dipermasalahkan dengan objek karena memang bentuk dari keduanya yang mirip. Namun apabila dicermati lebih lanjut, pelengkap memiliki wujud frasa yang lebih banyak, seperti frasa nominal, verbal, adjektival, dan preposisional. Fungsi Pel dapat hadir di belakang predikat apabila objek tidak hadir (Alwi, dkk., 2003). Apabila $\mathrm{O}$ dapat menjadi $\mathrm{S}$ ketika kalimat aktif diubah menjadi kalimat pasif, Pel tidak dapat menjadi $\mathrm{S}$ akibat pemasifan kalimat. Pel juga tidak dapat diganti dengan -nya kecuali dalam kombinasi preposisi selain di, ke, dari, dan akan.

Komplemen yang memiliki sifat paling fleksibel adalah keterangan (K). Hal ini disebabkan sifatnya yang manasuka, sehingga posisinya dapat berpindahpindah dalam suatu konstruksi kalimat. Unsur K dapat berupa frasa nominal, frasa preposisional, atau frasa adverbial (Suhardi, 2013). Adapun jenis-jenis keterangan, seperti: keterangan waktu, tempat, tujuan, alat, cara, penyerta, perbandingan, kesalingan, sebab, syarat, pengandaianm konsensif (tak bersyarat), dan keterangan akibat/hasil.

Selain fungtor yang berperan penting dalam kalimat, terdapat juga konjungtor yang menjadi penghubung tiap satuan bahasa. Konjungtor tersebut terbagi menjadi konjungtor koordinatif, korelatif, dan subordinatif yang terdapat dalam sebuah kalimat. Terdapat juga konjungtor yang menghubungkan satu kalimat dengan kalimat yang lain untuk menjaganya agar tetap berkoherensi. Konjungsi dalam kalimat seperti konjungsi koordinatif, meliputi: kata sedangkan, seperti, dan, atau, tetapi, sedangkan konjungsi korelatif yaitu baik...maupun ... ; tidak hanya...tetapi... ; demikian rupa...sehingga... (Busri \& Badrih, 2018). Konjungtor subordinatif, meliputi: kata sesudah, setelah, sementara, sapai, sejak, tatkala, sekalipun, karena, sehingga dan sebagainya. Konjungsi antarkalimat yang menghubungkan satu kalimat dengan kalimat lain, yaitu: biarpun demikian, meskipun demikian, sesungguhnya, oleh karena itu, dan sebagainya. Kesalahan fungtor dan konjungtor yang terjadi tentunya menyebabkan ketidakefektifan kalimat. Kalimat efektif juga berarti kalimat yang berhasil guna atau tepat guna (Rahardi, 2009; Rahayu, 2007). Adapun keefektifan kalimat tersebut meliputi kesepadanan struktur, kecermatan, kehematan kata, kepararelan bentuk, dan kelogisan makna.

\section{METODE}

Penelitian ini merupakan penelitian deksriptif kualitatif karena berusaha memahami fenomena tentang subjek penelitian. Subjek diteliti secara holistik dengan cara deskripsi dalam bentuk kata-kata dan bahasa. Fenomena ini pada suatu konteks khusus yang alamiah dan dengan memanfaatkan berbagai metode ilmiah (Moleong, 2007) secara apa adanya (Sukmadinata, 2011). Prosedur penelitian dengan mendeskripsikan bentuk-bentuk penyimpangan pemakaian kaidah fungtor-fungtor kalimat bahasa Indonesia para mahasiswa program Magister dalam menulis artikel jurnal.

Objek penelitian ini adalah penyimpangan kaidah fungtor bahasa. Sumber data penelitian ini adalah mahasiswa program Magister Pendidikan Bahasa Indonesia, Universitas Sanata Dharma Yogyakarta. Instrumen penelitian yang digunakan dalam penelitian ini adalah kartu data. Selain itu, data penelitian ini 
adalah kalimat-kalimat dalam artikel jurnal mahasiswa yang mengandung penyimpangan kaidah berbahasa Indonesia.

Teknik pengumpulan data menggunakan teknik catat. Tahapan yang dilakukan: 1) mencatat kalimat-kalimat yang mengandung kesalahan fungtor dalam artikel jurnal mahasiswa, serta 2) membuat tabulasi data sebagai alat bantu dalam mencatat bentuk-bentuk penyimpangan yang ditemukan. Metode yang digunakan dalam tahap analisis data adalah metode padan. Artinya, alat penentu metode padan ini berada di luar, terlepas dan tidak menjadi bagian dari bahasa yang bersangkutan (Sudaryanto, 2015). Dalam hal ini jenis metode padan digunakan untuk menganalisis pengawet bahasa atau tulisan dengan teknik Pilah Unsur Penentu (PUP) untuk meneliti kesalahan fungtor.

\section{HASIL DAN PEMBAHASAN}

Dalam analisis data, ditemukan kesalahan berbahasa, seperti: kesalahan fungtor kalimat, kesalahan konjungtor, kesalahan fungtor dan konjungtor, serta ketidakefektifan gagasan. Kesalahan fungtor kalimat terkait dengan tidak hadirnya fungsi inti seperti subjek dan predikat, bahkan keduanya. Kesalahan konjungsi terkait dengan konjungtor ganda, tidak adanya konjungtor, hingga kesalahan peletakkan konjungtor, sedangkan ketidakefektifan gagasan terkait dengan kehematan makna dan kepaduan gagasan. Beberapa hal yang disebutkan penulis tersebut merupakan bentuk penyimpangan yang ditemukan dan akan dipaparkan dalam pembahasan mengenai kategorisasi penyimpangan. Penulis akan memaparkan sebab-sebab penyimpangan setelahnya.

\section{Kategorisasi Penyimpangan}

Kategorisasi penyimpangan dalam artikel ini menunjukkan bentuk-bentuk penyimpangan yang ditemukan dalam data dan telah diklasifikasikan menjadi tiga garis besar, yaitu kesalahan fungtor, kesalahan konjungtor atau konjungsi, dan adanya ketidakefektifan gagasan.

\section{a. Kesalahan Fungtor}

Fungtor merupakan jabatan atau fungsi satuan gramatik yang membangun kalimat atau bahasa, meliputi subjek $(\mathrm{S})$, predikat $(\mathrm{P})$, objek $(\mathrm{O})$, pelengkap (Pel), dan keterangan (K) (Suhardi, 2013). Kesalahan yang ditemukan dalam artikel jurnal mahasiswa yaitu tidak hadirnya fungtor inti dalam kalimat. Berikut merupakan pemaparannya.

\section{Tidak Adanya Fungtor Subjek}

Suatu pernyataan dapat dikatakan sebagai kalimat jika di dalamnya sekurang-kurangnya terdapat predikat dan subjek, sekalipun nantinya disertai dengan objek, pelengkap, keterangan, maupun tidak (Busri \& Badrih, 2018). Hal ini bergantung pada tipe verba dalam kalimat yang bersangkutan. Dalam artikel jurnal yang dianalisis, terdapat 14 bentuk kebahasaan yang tidak dihadiri oleh fungtor S. Adapun cuplikan kalimat yang tidak bersubjek sebagai berikut.

a) Harapannya ketika tumbuh dewasa dapat menjadi pribadi yang digambarkan dalam setiap ritual upacara tersebut.

b) Pada tabel 1.1 telah dipaparkan bahwa terdapat beberapa leksikon yang menunjukkan kegiatan nyawah sebagai bentuk representasi cara berpikir masyarakat Sunda.

Kalimat (a) di atas dikatakan tidak memiliki subjek karena hanya terdapat fungtor K dan P. Frasa ketika tumbuh dewasa merupakan keterangan waktu. Hal 
ini ditandai dengan ketika yang menandai suatu periode tertentu, sedangkan kata harapannya merupakan suatu bentuk modalitas. Kalimat (b) juga dikatakan tidak memiliki fungtor S karena kalimat tersebut tidak memiliki kejelasan terkait siapa yang memaparkan berbagai leksikon dalam kegiatan nyawah. Kalimat tersebut akan tepat apabila diperbaiki seperti berikut.

a) Harapannya, ketika tumbuh dewasa, si anak dapat menjadi pribadi yang digambarkan dalam setiap ritual upacara tersebut.

b) Pada tabel 1.1 peneliti telah memaparkan beberapa leksikon yang menunjukkan kegiatan nyawah sebagai bentuk representasi cara berpikir masyarakat Sunda.

\section{Tidak Adanya Fungtor Predikat}

Predikat merupakan unsur wajib dalam sebuah kalimat (Alwi, dkk., 2003). Predikat sebagai unsur pokok kerap disertai dengan fungtor $\mathrm{S}$ disebelah kiri atau sebelumnya dan diikuti oleh unsur $\mathrm{O}$, Pel, dan/atau K di sebelah kanan jika ada. Dalam artikel jurnal yang dianalisis, terdapat 15 bentuk kebahasaan yang tidak dihadiri oleh fungtor wajib/inti ini. Adapun contoh bentuk kebahasaan yang tidak berpredikat sebagai berikut.

a) Berdasarkan tradisi lisan secara turun temurun, kemunculan tradisi pedalangan gaya Surakarta dan Ngayogyakarta karena peran Kiai Panjang Mas dan Nyai Panjang Mas sebagau dalang legendaris.

b) Duranti (1997:27), budaya merupakan pengetahuan di mana masyarakat memiliki pola pikir, cara memahami dunia, membuat inferens dan ramalan yang sama antarmasyarakat tersebut.

Konstruksi kebahasaan (a) di atas dikatakan tidak memiliki predikat karena subjek kemunculan tradisi pedalangan gaya Surakarta dan Ngayogyakarta yang berfungsi sebagai $\mathrm{P}$ diikuti oleh fungsi K yaitu karena peran Kiai Panjang Mas dan Nyai Panjang Mas sebagai dalang legendaris yang merupakan jenis keterangan sebab. Hal ini ditandai dengan adanya penghubung karena. Sama halnya dengan (a), konstruksi (b) juga dikatakan tidak memiliki predikat. Apabila dianalisis pola kalimatnya, didapati bahwa kata Duranti menduduki fungsi S, dan diikuti oleh fungtor O yaitu budaya, sehingga tidak diketahui hal yang dilakukan oleh pelaku (subjek) karena tidak ada predikatnya. Konstruksi-konstruksi tersebut akan lebih tepat apabila direvisi sebagai berikut.

a) Berdasarkan tradisi lisan secara turun temurun, kemunculan tradisi pedalangan gaya Surakarta dan Ngayogyakarta tidak lepas dari peran Kiai Panjang Mas dan Nyai Panjang Mas sebagau dalang legendaris.

b) Duranti (1997:27) mengatakan bahwa budaya merupakan pengetahuan di mana masyarakat memiliki pola pikir, cara memahami dunia, membuat inferens dan ramalan yang sama antarmasyarakat tersebut.

\section{Tidak Adanya Fungtor Objek}

Pada dasarnya, fungtor objek merupakan fungtor yang tidak wajib hadir didalam kalimat. Namun, dalam predikat yang berverba transitif, fungtor $\mathrm{O}$ wajib hadir (Ramlan, 2005). Namun, dalam artikel jurnal yang ditulis oleh mahasiswa, 
terdapat tiga bentuk kebahasaan yang predikatnya tidak menyertakan fungtor $\mathrm{O}$. Berikut merupakan cuplikan kalimatnya.

a) Manusia harus menghindari agar selamat, jika tidak mampu menghindar dari sengkolo maka kesusahan dan maut pasti cepat menjemput

Predikat dalam kalimat tersebut adalah kata kerja transitif. Hal itu berarti objek harus berada di samping predikat (Alwi, dkk, 2003). Namun dalam kalimat tersebut, fungsi objek (O) tidak hadir. Kalimat di atas juga berverba transitif yang ada dalam kalimat aktif. Dalam kalimat tersebut, fungtor P langsung diikuti oleh keterangan, sehingga timbullah pertanyaan Apa yang harus dihindari manusia agar selamat? Selain itu, kalimat tersebut dapat diurai menjadi dua karena mengandung dua pokok pikiran. Pokok pikiran itu, yaitu: 1) pernyataan keharusan manusia menghindari sengkolo, dan 2) akibat dari tidak dapat menghindari sengkolo. Untuk itu, kalimat di atas hendaknya diperbaiki seperti berikut.

a) Manusia harus menghindari sengkolo agar selamat. Apabila manusia tidak mampu menghindar dari sengkolo, kesusahan dan maut pasti cepat menjemput.

\section{Tidak Adanya Fungtor Subjek dan Predikat}

Kontstruksi kebahasaan yang tidak menyertakan fungsi S dan P tidak dapat disebut sebagai kalimat, tetapi bisa saja berupa frasa. Pada kenyataannya, terdapat 13 konstruksi kebahasaan seperti itu yang ditemukan dalam artikel jurnal mahasiswa.

a) Seperti kehidupan masyarakat Jawa yang selalu mementingkan kerukunan antarsaudara kandung melebihi apapun.

b) Sejak antropolinguistik lahir di Amerika Serikat sekitar abad 19 sebagai interdisipliner (mengkaji antropologi dan linguistik).

Melalui cuplikan kalimat di atas, dapat diketahui bahwa fungtor $\mathrm{S}$ dan $\mathrm{P}$ tidak hadir. Kalimat (a) dan (b) hanya memiliki fungtor K. Hal ini ditandai dengan kata seperti pada konstruksi (a) dan kata sejak pada konstruksi (b). Konstruksi (a) merupakan sebuah keterangan perbandingan, sedangkan konstruksi (b) merupakan keterangan waktu. Untuk membuat konstruksi tersebut menjadi kalimat yang utuh, kata seperti dan sejak dapat dihilangkan.

a) Kehidupan masyarakat Jawa selalu mementingkan kerukunan antarsaudara kandung melebihi apapun.

b) Antropolinguistik lahir di Amerika Serikat sekitar abad 19 sebagai interdisipliner ilmu (mengkaji antropologi dan linguistik).

\section{b. Kesalahan Konjungtor}

Konjungtor dapat disebut dengan kata tugas yang fungsinya menguhubungkan dua klausa atau lebih (Busri \& Badrih, 2018). Data yang mengandung kesalahan konjungtor sebagai berikut.

\section{Konjungtor Ganda}

Konjungtor ganda yang dimaksud adalah adanya dua atau lebih konjungtor di dalam kalimat, sehingga menimbulkan kelewahan. Berdasarkan analisis yang telah dilakukan sebelumnya, ditemukan empat kalimat yang menyertakan 
konjungtor ganda. Berikut merupakan cuplikan kalimat yang mengandung konjungtor ganda tersebut.

a) Jika kata hakasuk dipahami dari sudut pandang morfologi kata, maka dapat bermakna "melepaskan" karena telah dibubuhi imbuhan prefiks (ha-).

b) Jika Duranti (1997:1) memandang antropologi linguistik digunakan secara bervariasi dengan linguistik antropologi, maka Foley (1997:3) berpendapat bahwa linguistik antropologi memandang dan mengkaji bahasa dari sudut pandang antropologi, budaya, dan bahasa untuk menemukan makna dibalik pemakaiannya.

Dalam kedua cuplikan di atas, dapat diketahui adanya kesamaan kesalahan dalam pemberian konjungtor. Kesalahan tersebut adalah adanya konjungtor jika di awal kalimat dan konjungtor maka sebagai penghubung antarklausa. Kata maka merupakan konjungsi untuk menyatakan akibat. Jika dan maka tidak dapat hadir bersama dalam sebuah kalimat karena menimbulkan keteksaan gagasan.

a) Jika kata hakasuk dipahami dari sudut pandang morfologi kata, hal ini dapat bermakna "melepaskan", karena telah dibubuhi imbuhan prefiks (ha-).

b) Jika Duranti (1997:1) memandang antropologi linguistik secara bervariasi dengan linguistik antropologi, Foley (1997:3) berpendapat bahwa linguistik antropologi memandang dan mengkaji bahasa dari sudut pandang antropologi, budaya, dan bahasa untuk menemukan makna dibalik pemakaiannya.

\section{Tidak Adanya Konjungtor}

Konjungtor berfungsi menghubungkan dua satuan kebahasaan. Kehadirannya sangat penting dalam sebuah konstruksi kalimat majemuk. Apabila tidak ada konjungtor yang menghubungkan dua satuan kebahasaan, kerancuan maupun keambiguanlah yang akan terjadi. Berdasarkan temuan yang diperoleh, terdapat empat data yang tidak menghadirkan konjungtor di dalamnya. Berikut merupakan cuplikan kalimat yang tidak menyertakan konjungtor.

a) Soreng nggana berasal dari suro ing (juwara dalam) nggana (peperangan) yang bermakna sebagai penjaga yang selalu menang dalam peperangan melawan hal-hal buruk.

Kekeliruan dalam kalimat tersebut adalah tidak hadirnya konjungsi untuk menghubungkan penjelasan frasa soreng nggana yang berasal dari kata suro ing dan nggana. Untuk menghubungkan kedua satuan bahasa tersebut dapat menambahkan konjungsi koordinatif dan di antara keduanya.

a) Soreng nggana berasal dari kata suro ing (juwara dalam) dan nggana (peperangan) yang bermakna sebagai penjaga yang selalu menang dalam peperangan melawan hal-hal buruk.

\section{Kesalahan Peletakkan Konjungtor}

Peletakan posisi kedua jenis fungtor tidak dapat disamakan. Namun, 23 kalimat yang salah dalam peletakkan konjungtor tersebut. 
a) Maka agar dapat tenang, tentram dan selamat mereka mengadakan ritual tersebut.

b) Pada satu pihak, manusia adalah pencipta kebudayaan, namun di pihak lain, kebudayaan yang menciptakan manusia sesuai dengan lingkungannya, maka terjalin hubungan timbal balik yang erat dan padu antara manusia, kebudayaan dan juga bahasa.

c) Sehingga, manusia hendaknya mengingat akan adanya Tuhan.

d) Sedangkan, maksud pernyataan bahasa berfungsi sebagai sarana adalah bahwa kebuadayaan yang sifatnya turun temurun tentu diwariskan melalui bahasa, karena bahasa adalah alat komunikasi.

Kalimat (a), (c) dan (d) pada dasarnya memiliki pola kesalahan yang serupa. Kata maka, sehingga, dan sedangkan merupakan konjungsi intrakalimat, sehingga kurang tepat apabila diletakkan pada awal kalimat. Kehadiran kata maka, sehingga, dan sedangkan dalam konstruksi sintaksis tersebut tidak berpengaruh terhadap makna kalimat, sehingga dapat dihilangkan. Solusi lain adalah kalimatkalimat tersebut digabungkan dengan kalimat yang mendahuluinya. Sedikit berbeda dengan kalimat (a), (c), dan (d), kalimat (b) memiliki kesalahan pada kata namun. Konjungsi namun merupakan salah satu jenis konjungsi antarkalimat, sehingga seharusnya berada di awal kalimat, tidak diletakkan setelah tanda baca koma (,).

a) Agar dapat tenang, tentram dan selamat mereka mengadakan ritual tersebut.

b) Pada satu pihak, manusia adalah pencipta kebudayaan. Namun di pihak lain, kebudayaan menciptakan manusia sesuai dengan lingkungannya, maka terjalin hubungan timbal balik yang erat dan padu antara manusia, kebudayaan dan juga bahasa.

c) Manusia hendaknya mengingat akan adanya Tuhan.

d) Maksud pernyataan bahasa berfungsi sebagai sarana adalah bahwa kebuadayaan yang sifatnya turun temurun tentu diwariskan melalui bahasa, karena bahasa adalah alat komunikasi.

\section{c. Kesalahan Fungtor dan Konjungtor}

Selain kesalahan fungtor dan konjungtor, ditemukan empat data kalimat yang melanggar kaidah fungtor dan konjungtor sekaligus. Berikut merupakan cuplikan kalimat yang mengandung kesalahan fungtor dan konjungtor tersebut.

a) Masyarakat yang ada kaitannya dengan sengkolo, maka berhubungan dengan Bhatara Kala sebagai pihak penghegemoni yang mendorong mereka melakukan ruwatan agar terhindar dari sengkolo tersebut.

b) Menilik pemahaman tersebut, maka sebelum melaksanakan upacara natah, diadakan upacara khusus, tentu tiap upacara terdapat mantra yang digunakan.

Dalam cuplikan kalimat (a) menunjukkan bahwa kata maka sebagai sebuah konjungsi antara klausa pertama dan kedua. Namun, karena kehadiran konjungsi maka tersebut konstruksi Masyarakat yang ada kaitannya dengan sengkolo tidak dapat disebut sebagai klausa karena hanya memiliki fungtor subjek (S). Selain itu, bentuk berhubungan dengan Bhatara Kala sebagai pihak penghegemoni yang 
mendorong mereka melakukan ruwatan agar terhindar dari sengkolo tersebut juga tidak memiliki fungsi predikat (P), sehingga tidak dapat disebut sebagai kalimat. Untuk itu, kata maka seharusnya dihilangkan agar bentuk-bentuk tersebut memenuhi syarat sebuah klausa maupun kalimat.

Serupa dengan (a), konstruksi (b) juga mengandung dua kesalahan sekaligus. Kata maka dalam konstruksi tersebut (b) tepat karena klausa sebelum melaksanakan upacara natah bukan merupakan akibat dari klausa sebelumnya. Selain itu, fungsi subjek (S) tidak hadir dalam konstruksi kalimat tersebut. Klausa tentu tiap upacara terdapat mantra yang digunakan juga kurang tepat apabila bergabung dengan klausa sebelumnya karena memiliki ide atau poin berbeda yang bisa berdiri sendiri menjadi sebuah kalimat. Untuk itu, kedua kalimat di atas dapat diperbaiki dengan alternatif sebagai berikut.

a) Masyarakat yang berkaitan dengan sengkolo berhubungan dengan Bhatara Kala sebagai pihak penghegemoni. Hal ini bertujuan mendorong mereka melakukan ruwatan agar terhindar dari hal tersebut.

b) Berdasarkan pemahaman tersebut, sebelum melaksanakan upacara natah, masyarakat melaksanakan upacara khusus. Setiap upacara yang dilaksanakan memiliki mantra yang digunakan.

\section{d. Ketidakefektifan Gagasan}

Selain penyimpangan fungtor dan konjungtor kalimat, ditemukan 20 data kalimat yang tidak memenuhi syarat keefektifan gagasan. Pada dasarnya, ketidaktepatan penggunaan konjungtor dan penyimpangan kaidah fungtor menimbulkan ketidakefektifan kalimat. Dalam hal ini, ketidakefektifan kalimat yang dimaksud terkait dengan kehematan makna dan kepaduan gagasan dalam pembahasan kali ini. Kalimat efektif juga berarti kalimat yang berhasil guna atau tepat guna (Rahardi, 2009; Rahayu, 2007). Kehematan kata pada dasarnya merupakan sebuah prinsip ketercukupan dalam pemakaian bentuk kebahasaan, sedangkan kepaduan gagasan berupa prinsip kohenrensi yang terdapat dalam sebuah kalimat. Berikut merupakan penjelasannya.

a) Makna mengacu pada keseluruhan teks dalam kaitannya dengan suatu konteks yang lebih besar, konteks itu antaralain adalah pikiran, zaman, dan sistem nilai.

b) Narasi hasil terjemahan tersebut merupakan sumber data penelitian, langkah selanjutnya adalah merumuskan data penelitian yang berupa kutipan atau kata-kata mantra natah suwunan yang merupakan ungkapan syukur, ungkapan permohonan, dan ungkapan harapan.

c) Puser (pusar) merupakan penghubung antara ibu dan anak, dengan adanya tali puser sang ibu mampu memberikan nutrisi kepada sang bayi, puser juga merupakan saluran bernafas sang bayi, dengan adanya puser inilah seorang ibu memiliki hubungan batin yang erat dengan bayi.

d) Dengan demikian, diambil dari artinya berkehendak agar pantas, asri atau bagus bentuk bangunan yang dibuat itu, kitri, kata kitri ini sebagai ayoming kekitren yang maksudnya selalu dalam rasa tentram dan tidak tegang dalam menghadapi segala persoalan atau masalah. 
Dalam konstruksi kalimat (a), terdapat dua ide pokok kalimat yang dapat dipisah dan digunakan untuk membangun kalimat yang baru. Klausa makna mengacu pada keseluruhan teks dalam kaitannya dengan suatu konteks yang lebih besar dan konteks itu antaralain adalah pikiran, zaman, dan sistem nilai tidak berkoherensi apabila dipadukan menjadi sebuah kalimat. Selain itu, terdapat kata antara lain dan adalah yang mempunyai tujuan sama, yaitu menyebutkan bagian dari konteks. Namun, penggunaan kedua kata tersebut secara bersamaan kiranya kurang tepat. Kata antara lain digunakan digunakan untuk menyebutkan sebagian dari apa yang hendak dibicarakan, sedangkan kata adalah digunakan apabila sesuatu yang didefinisikan diawali dengan kata benda.

Dalam kalimat (b), terdapat dua kesalahan. Kesalahan yang pertama adalah adanya dua ide atau makna berbeda dalam klausa pertama dan klausa kedua. Pada dasarnya, klausa tersebut dapat dipisah dan digunakan untuk membangun kalimat yang baru. Selain itu, terdapat penggunaan konjungsi yang yang hadir dua kali. Agar kalimat tersebut mudah untuk dipahami, salah satu konjungsi "yang" dihilangkan dalam kalimat tersebut. Hampir sama dengan poin (b), konstruksi kalimat dalam poin (c) pada dasarnya memiliki empat gagasan yang terpisah dan akan lebih baik apabila berdiri menjadi suatu kalimat sendiri. Konstruksi kalimat (d) merupakan konstruksi yang berantakan sehingga tidak berterima karena inti kalimat tidak dapat ditangkap dengan jelas. Kalimat ini perlu disederhanakan. Berikut merupakan perbaikan-perbaikan kalimat di atas.

a) Makna mengacu pada keseluruhan teks dalam kaitannya dengan suatu konteks yang lebih besar. Konteks itu berupa pikiran, zaman, dan sistem nilai.

b) Narasi hasil terjemahan tersebut merupakan sumber data penelitian. Langkah selanjutnya adalah merumuskan data penelitian berupa kutipan atau kata-kata mantra natah suwunan sebagai wujud dari ungkapan syukur, ungkapan permohonan, dan ungkapan harapan.

c) Puser (pusar) merupakan penghubung a ntara ibu dan anak. Dengan adanya tali puser, sang ibu mampu memberikan nutrisi kepada sang bayi. Puser juga merupakan saluran bernafas sang bayi. Melalui puser inilah seorang ibu memiliki hubungan batin yang erat dengan bayi.

d) Makna kitri sebagai ayoming kekitren berarti, manusia selalu berada dalam rasa tentram dan tidak tegang ketika menghadapi segala persoalan atau masalah.

\section{Sebab-Sebab Penyimpangan}

Penyimpangan fungtor dan konjungtor yang menyebabkan ketidakefektifan kalimat muncul akibat dua faktor. Hal tersebut berdasarkan analisis data yang telah dilakukan sebelumnya. Faktor tersebut dipaparkan sebagai berikut.

a. Faktor yang pertama adalah kesulitan mahasiswa menuangkan gagasan dalam bentuk kalimat. Ide maupun gagasan mungkin telah bermunculan dalam pemikiran mahasiswa. Namun, menyusun gagasan tersebut menjadi konstruksi kalimat yang baik dan benar merupakan suatu tantangan tersendiri. Misal pada data yang berbunyi, dengan demikian, diambil dari artinya berkehendak agar pantas, asri atau bagus bentuk bangunan yang dibuat itu, kitri, kata kitri ini sebagai ayoming kekitren yang maksudnya selalu dalam rasa tentram dan 
tidak tegang dalam menghadapi segala persoalan atau masalah. Kalimat tersebut menggambarkan penumpukkan informasi yang tidak dapat diurai dengan baik oleh mahasiswa, sehingga kalimat yang dituangkan pun menjadi kabur maknanya. Ide yang ingin dituangkan oleh mahasiswa dalam kalimat tersebut, yaitu: makna dari kata kitri. Kitri diambil dari frasa ayoming kekitren yang mempunyai makna bahwa manusia selalu berada dalam rasa tentram dan tidak tegang ketika menghadapi berbagai tantangan hidup.

b. Faktor yang kedua adalah kurangnya pemahaman mahasiswa terhadap kaidah kebahasaan. Kaidah kebahasaan yang dimaksud berupa syarat kalimat dan konjungsi yang menyertainya. Syarat kalimat ini terkait dengan kehadiran fungtor-fungtor, baik yang wajib maupun tidak wajib. Hal ini dapat diketahui dari banyak kesalahan yang terjadi akibat mahasiswa tidak memerhatikan unsur wajib ( $\mathrm{S}$ dan $\mathrm{P}$ ) dalam konstruksi kalimat yang disusun. Begitu juga dengan tidak hadirnya fungsi $\mathrm{O}$ dalam verba transitif. Hal ini kemudian menjadikan suatu kalimat tidak efektif. Kurangnya pemahaman mengenai konsep kebahasaan ini dikatakan oleh Suroso (2011) sebagai kesalahan intralingual. Kesalahan intralingual dapat disebut sebagai kesalahan yang terjadi akibat kerumitan bahasa yang dipelajari. Karena ketidaktahuannya, mahasiswa melakukan kesalahan seperti menggunakan konjungsi antarkalimat untuk menghubungan klausa, tidak menyertakan fungtor $\mathrm{O}$ dalam verba transitif, dan sebagainya.

\section{SIMPULAN}

Penyimpangan kaidah fungtor-fungtor kalimat bahasa Indonesia yang ditemukan dalam artikel jurnal mahasiswa program Magister berkaitan dengan tidak hadirnya fungtor tersebut dalam kalimat. Fungtor yang tidak hadir tersebut diklasifikasikan menjadi fungtor subjek (S), predikat (P), objek (O), dan ketidakhadiran dua fungtor inti sekaligus, yaitu $\mathrm{S}$ dan $\mathrm{P}$. Berdasarkan analisis data yang telah dilakukan, terdapat: 45 kesalahan fungtor, 31 kesalahan konjungtor, empat kesalahan fungtor dan konjungtor sekaligus, dan 20 ketidakefektifan gagasan. Faktor penyebab penyimpangan tersebut, yaitu: kesulitan mahasiswa menuangkan gagasan dalam bentuk kalimat dan kurangnya pemahaman mahasiswa terhadap kaidah kebahasaan.

\section{UCAPAN TERIMA KASIH}

Penulis mengucapkan terima kasih kepada Kementerian Riset dan Teknologi Badan Riset dan Inovasi Nasional, DRPM atas Hibah Penelitian Tesis Magister tahun 2020.

\section{DAFTAR PUSTAKA}

Alwi, H., Lapoliwa, H., \& Darmowidjojo, S. (2003). Tata Bahasa Baku Bahasa Indonesia. Jakarta: Balai Pustaka.

Azmi, N, \& Bahry, R. (2018). Analisis Kesalahan Berbahasa dalam Artikel Jurnal di Lingkungan Universitas Syiah Kuala. Master Bahasa, 6(2), 149-160.

Busri, H., \& Badrih, M. (2018). Linguistik Indonesia: Pengantar Memahami Hakikat Bahasa. Malang: Madani Media.

Khairah, M., \& Ridwan, S. (2015). Sintaksis: Memahami Satuan Kalimat Perspektif Fungsi. Jakarta: Bumi Aksara.

Mariyana, S. (2019). Analisis Kesalahan Kalimat dalam Artikel Jurnal Pendidikan 
dan Keguruan 2014 Program Pascasarjana Universitas Terbuka. Metafora, $5(2), 131-140$.

Moleong, L. J. (2007). Metodologi Penelitian Kualitatif. Bandung: PT Remaja Rosdakarya.

Morizkavenlia, D., \& Sudarmini. (2019). Kesalahan Berbahasa pada Jurnal Karimah Periode Agustus 2017 dan Kaitannya dengan Pembelajaran Karya Ilmiah di SMA Kelas XI. Genre, 1(1), 42-45.

Nurwicaksono, B. D., \& Amelia, D. (2018). Analisis Kesalahan Berbahasa Indonesia pada Teks Ilmiah Mahasiswa. Aksis, 2(2), 138-153.

Rahardi, K. (2009). Penyuntingan bahasa indonesia untuk Karang-Mengarang. Jakarta: Erlangga.

Rahayu, M. (2007). Bahasa Indonesia di Perguruan Tinggi. Jakarta: Grasindo.

Ramaniyar, E. (2017). Analisis Kesalahan Berbahasa Indonesia. Edukasi, 15, 7080.

Ramlan. (2005). Ilmu Bahasa Indonesia Sintaksis. Yogyakarta: C.V Karyono.

Sudaryanto. (2015). Metode dan Aneka Teknik Analisia Bahasa. Yogyakarta: Sanata Dharma University Press.

Suhardi. (2013). Sintaksis. Yogyakarta: UNY Press.

Sukmadinata, N. S. (2011). Metode Penelitian Pendidikan. Bandung: PT Remaja Rosdakarya.

Suroso, E. (2011). Bidang-Bidang Kesalahan dalam Pembelajaran Bahasa Indonesia Sebagai B-2. Aktif, 16(1), 1-9. 